\title{
PENGARUH STRATEGI PEMBELAJARAN REACT TERHADAP KEMAMPUAN BERPIKIR KRITIS DITINJAU DARI KEMAMPUAN AWAL SISWA SMP
}

\author{
Julita Mawarni $^{1}$, Ali Syahbana ${ }^{2}$, Ety Septiati ${ }^{3}$ \\ FKIP, Universitas PGRI Palembang ${ }^{1,2,3}$ \\ syahbanapgri545@gmail.com ${ }^{2}$
}

\begin{abstract}
ABSTRAK
Tujuan penelitian ini adalah (1) Mengetahui ada atau tidak adanya pengaruh strategi pembelajaran REACT terhadap kemampuan berpikir kritis siswa secara keseluruhan, (2) Mengetahui ada atau tidak adanya pengaruh strategi pembelajaran REACT terhadap kemampuan berpikir kritis ditinjau dari kemampuan awal siswa menurut masing-masing level, dan (3) Mengetahui ada atau tidak adanya interaksi antara pembelajaran REACT dengan kemampuan awal (tinggi, sedang, rendah) terhadap kemampuan berpikir kritis siswa di SMP Sanudin Pangkalan Balai. Metode yang digunakan metode eksperimen kategori Posttest-Only Control Group Design. Penelitian ini dilakukan pada siswa kelas VIII.2 sebagai kelas eksperimen dan VIII.1 sebagai kelas kontrol. Teknik pengumpulan data menggunakan teknik tes, data dianalisis dengan menggunakan independen Anova dua jalur pada taraf signifikan 5\%. Hasil penelitian ini menunjukkan (1) Ada pengaruh strategi pembelajaran REACT terhadap kemampuan berpikir kritis siswa secara keseluruhan, (2) Ada pengaruh strategi pembelajaran REACT terhadap kemampuan berpikir kritis ditinjau dari kemampuan awal siswa menurut masing-masing level, dan (3) Tidak ada interaksi antara pembelajaran REACT dengan kemampuan awal (tinggi, sedang, rendah) terhadap kemampuan berpikir kritis siswa kelas VIII tahun pelajaran 2017/2018 di SMP Sanudin Pangkalan Balai.
\end{abstract}

Kata kunci : berpikir kritis, strategi REACT, kemampuan awal

\begin{abstract}
The purpose of this research is (1) to know whether or not there is influence of learning strategy of Relating, Experiencing, Applying, Cooperating, Transfering (REACT) to students' critical thinking ability as a whole, (2) Knowing there is or no influence of Relating learning strategy, Experiencing, Applying, Cooperating, Transfering (REACT) to critical thinking ability in terms of students' initial ability according to each level and (3) Knowing there is or is no interaction between learning Relating, Experiencing, Applying, Cooperating, Transfering (REACT) with early (high, medium, low) abilities of students' critical thinking skills at Sanudin Pangkalan Balai Junior High School. The method used the Posttest-Only Control Group Design category experimental method. This research was conducted on students of class VIII.2 as experimental class and VIII.1 as control class. Technique of collecting data using test technique, the data were analyzed by using independent twochannel Anova at 5\% significant level. The results of this research show (1) There is influence of learning strategy of Relating, Experiencing, Applying, Cooperating, Transfering (REACT) to the critical thinking ability of students as a whole, (2) There is influence of learning strategy of Relating, Experiencing, Applying, Cooperating, Transfering (REACT) (3) There is no
\end{abstract}




\begin{abstract}
interaction between learning Relating, Experiencing, Applying, Cooperating, Transfering (REACT) with the initial ability (high, medium, low) to students' critical thinking skills class VIII academic year 2016/2017 at SMP Sanudin Pangkalan Balai.
\end{abstract}

Keywords: critical thinking, REACT strategy, initial ability

\title{
PENDAHULUAN
}

Menurut Permendiknas Nomor 23 Tahun 2006 (Muhaimin dkk, 2008: 337) salah satu tujuan dari pembelajaran matematika di dalam lampiran tentang standar isi yaitu membangun, menerapkan serta menunjukkan kemampuan berpikir logis, kritis, kreatif, dan inovatif dalam pengambilan keputusan. Cara berpikir seperti ini dapat dikembangkan melalui proses pembelajaran matematika, karena matematika memiliki struktur dan keterkaitan yang kuat dan jelas antar konsepnya sehingga memungkinkan siapapun yang mempelajarinya terampil berpikir rasional. Namun pemahaman siswa terhadap matematika masih kurang, apalagi kemampuan berpikir matematisnya, hal ini disebabkan sifat matematika yang abstrak dan juga cara pembelajaran yang kurang tepat. Permasalahan yang sering terjadi ini dalam kegiatan pembelajaran masih dominannya peran guru dalam proses kegiatan belajar-mengajar, siswa cendrung pasif dan hanya mendengarkan apa yang diterangkan oleh guru kemudian mempraktekkannya, siswa tidak didorong untuk mengeluarkan pendapatnya sendiri.

Berdasarkan observasi yang telah dilakukan di SMP Sanudin Pangkalan Balai, diperoleh informasi dari kepala sekolah bahwa kebiasaan guru memberikan pembelajaran dengan metode ceramah dan hanya mencatat membuat siswa menjadi kurang aktif dan cara berpikir pun tidak kritis. Hal ini sejalan ini dengan pengakuan guru mata pelajaran matematika di SMP Sanudin Pangkalan Balai bahwa guru tersebut kesulitan untuk membuat variasi dalam kegiatan pembelajaran karena siswa sudah terbiasa diberi dan hanya menerima informasi sehingga siswa merasa kesulitan untuk mencari sendiri informasi yang mereka butuhkan.

Oleh karena itu untuk mengembangkan kemampuan berpikir kritis siswa diperlukan inovasi dalam kegiatan belajar mengajar. Berpikir kritis adalah aktivitas terampil, yang bisa dilakukan dengan lebih baik atau sebaliknya dan pemikiran kritis yang baik akan menemui beragam standar intelektual, seperti kejelasan, relevansi, kecukupan, koherensi, dan lain-lain (Fisher, 2008: 13). Untuk mengatasi hal tersebut salah satu yang dilakukan adalah pembelajaran dengan menggunakan strategi pembelajaran $R E A C T$.

Strategi REACT adalah suatu pendekatan pembelajaran kontekstual yang berhubungan dengan pengalaman dan penerapan pemahaman dalam berbagai konteks, baik di dalam maupun di luar kelas untuk menyelesaikan permasalahan (Noor dan Raisah, 2015: 198). Menurut Cord (1999) Strategi REACT merupakan strategi pembelajaran kontekstual terdiri dari 5 strategi yang harus tampak yaitu : (1) Relating (mengaitkan), (2) Experiencing (mengalami), (3) Applying (menerapkan), (4) Cooperating (bekerjasama), (5) Transferring (mentransfer). Relating (mengaitkan) adalah belajar dalam konteks pengalaman kehidupan nyata atau pengetahuan yang sebelumnya. Experiencing (mengalami) adalah strategi belajar dengan belajar melalui eksplorasi, penemuan dan penciptaan. Berbagai pengalaman dalam kelas dapat mencakup penggunaan manipulatif, aktivitas pemecahan masalah 
dan laboratorium. Applying (menerapkan) adalah belajar dengan menempatkan konsep-konsep untuk digunakan, dengan memberi latihan-latihan yang realistik dan relevan. Cooperating (bekerjasama) adalah belajar dalam konteks sharing, merespon dan berkomunikasi dengan para pembelajar lainnya. Kemudian Transferring (mentransfer) adalah belajar dengan menggunakan pengetahuan dalam konteks baru.

Kemampuan berpikir merupakan salah satu modal yang harus dimiliki siswa sebagai bekal dalam menghadapi perkembangan ilmu pengetahuan dan teknologi pada masa sekarang ini. Kemampuan seseorang untuk dapat berhasil dalam kehidupannya antara lain ditentukan oleh kemampuan berpikirnya, terutama dalam memecahkan masalah-masalah kehidupan yang dihadapinya (Ibrahim dalam Dwijananti dan Yulianti, 2010: 111). Fisher (2008: 3) mengemukakan bahwa berpikir kritis adalah aktivitas terampil, yang bisa dilakukan dengan lebih baik atau sebaliknya dan pemikiran kritis yang baik akan menemui beragam standar intelektual, seperti kejelasan, relevansi, kecukupan, koherensi, dan lain-lain.

Menurut Ennis (Syahbana, 2012: 20) kemampuan berpikir kritis mencakup 4 indikator, yaitu : (1) Aspek yang berkaitan dengan konsep, (2) Aspek yang berkaitan dengan generalisasi, (3) Aspek yang berkaitan dengan keterampilan dan algoritma, dan (4) Aspek yang berkaitan dengan pemecahan masalah.

Kemampuan awal (Entry Behavior) adalah kemampuan yang telah diperoleh siswa sebelum dia memperoleh kemampuan terminal tertentu yang baru. Kemampuan awal menunjukkan status pengetahuan dan keterampilan siswa sekarang untuk menuju ke status yang akan datang yang diinginkan guru agar tercapai oleh siswa. Dengan kemampuan ini dapat ditentukan dari mana pengajaran harus dimulai. Kemampuan terminal merupakan arah tujuan pengajaran diakhiri. Jadi, pengajaran berlangsung dari kemampuan awal sampai ke kemampuan terminal itulah yang menjadi tanggung jawab pengajar (Mukhtar, 2003:57).

Menurut Astuti (2015: 71) kemampuan awal juga bisa disebut dengan Prior Knowledge (PK) yang merupakan langkah penting di dalam proses belajar, dengan demikian setiap guru perlu mengetahui tingkat PK yang dimiliki para peserta didik. Dalam proses belajar, PK merupakan kerangka dimana peserta didik menyaring informasi baru dan mencari makna tentang apa yang sedang dipelajari olehnya. Setiap individu mempunyai kemampuan belajar yang berlainan. Kemampuan awal siswa dapat diukur melalui tes awal, interview, atau cara-cara lain yang cukup sederhana seperti melontarkan pertanyaan-pertanyaan secara acak dengan distribusi perwakilan siswa yang representatif.

Herawati (2013) telah melakukan penelitian tentang pembelajaran melalui Strategi REACT untuk meningkatkan Kemampuan Berpikir Kritis Matematis Siswa SMK di Kota Tasikmalaya. Berdasarkan penelitian tersebut, disebutkan bahwa siswa yang mengikuti pembelajaran melalui strategi REACT secara signifikan mengalami peningkatan kemampuan berpikir kritis matematisnya.

Penelitian Aziz (2014) juga menyimpulkan bahwa kemampuan berpikir kritis siswa yang menggunakan strategi REACT dengan pendekatan Education Games meningkat dan lebih baik daripada yang menggunakan pembelajaran konvensional, serta respon siswa terhadap pembelajaran strategi REACT dengan pendekatan Education Games positif.

Berdasarkan uraian di atas dan hasil penelitian yang dilakukan peneliti lain, dicoba menggunakan strategi pembelajaran REACT terhadap kemampuan berpikir kritis ditinjau dari kemampuan awal siswa di SMP Sanudin Pangkalan Balai. Tujuan 
dari penelitian ini adalah : (1) Mengetahui ada atau tidak adanya pengaruh strategi pembelajaran REACT terhadap kemampuan berpikir kritis siswa secara keseluruhan, (2) Mengetahui ada atau tidak adanya pengaruh strategi pembelajaran REACT terhadap kemampuan berpikir kritis ditinjau dari kemampuan awal siswa menurut masing-masing level, (3) Mengetahui ada atau tidak adanya interaksi antara pembelajaran REACT dengan kemampuan awal (tinggi, sedang, rendah) terhadap kemampuan berpikir kritis siswa di SMP Sanudin Pangkalan Balai.

\section{METODE}

Dalam penelitian ini metode yang digunakan adalah metode eksperimen Posstest-Only Control Group Design. Populasi yang digunakan dalam penelitian ini adalah seluruh siswa kelas VIII SMP Sanudin Pangkalan Balai Tahun Pelajaran 2017/2018. Pengambilan sampel menggunakan teknik Cluster Sampling yaitu pengambilan sampel secara kelompok. Terpilih sebagai sampel dalam penelitian ini adalah kelas VIII.2 sebagai kelas eksperimen dan kelas VIII.1 sebagai kelas kontrol.

Teknik pengumpulan data yang digunakan dalam penelitian ini adalah teknik tes. Tes diberikan sebanyak dua kali yaitu sebelum dilakukannya pembelajaran (kemampuan awal) dan sesudah pembelajaran (post-test). Siswa diberi perlakuan (treatment) dengan menggunakan strategi REACT (kelas eksperimen) dan pembelajaran konvensional (kelas kontrol). Tes soal matematika umum diberikan untuk mengetahui kemampuan awal siswa dan post-test diberikan untuk mengetahui kemampuan berpikir kritis siswa setelah pembelajaran. Materi yang digunakan adalah lingkaran. Variabel dari penelitian ini yaitu kemampuan berpikir kritis dalam pembelajaran strategi REACT, dan variabel kontrol yaitu kemampuan awal siswa. Teknik analisis data yang digunakan yaitu Uji-F (Anova).

\section{HASIL DAN PEMBAHASAN}

Jumlah pertemuan yang dilakukan selama penelitian di kelas eksperimen dan kelas kontrol adalah sebanyak lima kali pertemuan, dengan rincian satu kali pertemuan untuk mengetahui kemampuan awal siswa dengan memberikan soal tes matematika umum, tiga kali pertemuan untuk penerapan pembelajaran, dan satu kali pertemuan sebagai post-test di akhir pertemuan.

\section{Kemampuan awal siswa}

Untuk mengetahui kondisi kemampuan awal siswa diberikan soal tes matematika umum di awal pertemuan. Tes dilakukan dengan memberikan soal berbentuk pilihan ganda sebanyak 20 soal dengan materi lingkaran. Tes dilaksanakan di kelas eksperimen pada tanggal 14 Agustus 2017 dan kelas kontrol pada tanggal 14 Agustus 2017. Berdasarkan hasil perhitungan menunjukkan bahwa kemampuan awal siswa kelas eksperimen dan kelas kontrol sebelum diberikan perlakuan relatif sama. Hal ini dapat terlihat dari selisih skor rata-rata kelas eksperimen dan kelas kontrol tidak terlalu besar. Rata-rata skor kemampuan awal siswa kelas eksperimen sebesar 66,24 dan kelas kontrol sebesar 63,52.

\section{Kemampuan akhir siswa (Post-Test)}

Untuk mengetahui kemampuan berpikir kritis siswa setelah diberikan perlakuan dengan menggunakan strategi REACT pada kelas eksperimen dan pembelajaran konvensional pada kelas kontrol, dilakukan tes akhir. Tes akhir dilaksanakan di kelas eksperimen pada tanggal 28 Agustus 2017 dan kelas 
kontrol pada tanggal 28 Agustus 2017. Berdasarkan hasil perhitungan menunjukkan bahwa skor rata-rata kemampuan berpikir kritis matematis siswa kelas eksperimen sebesar 10,96 dan kelas kontrol sebesar 9,6. Jadi dapat disimpulkan bahwa kemampuan berpikir kritis matematis siswa pada kelas eksperimen lebih baik dibandingkan dengan kelas kontrol.

Selanjutnya terhadap hasil tes akhir dilakukan analisis inferesial sebagai berikut.

Tabel 1. Hasil uji normalitas

\begin{tabular}{lccl}
\hline Kelas & $X^{2}$ & $X^{2}$ tabel & Keterangan \\
\hline Eksperimen & 4,675 & 15,507 & $\begin{array}{l}\text { Data } \\
\text { berdistribusi } \\
\text { normal }\end{array}$ \\
Kontrol & 6,5 & 14,067 & $\begin{array}{l}\text { Data } \\
\text { berdistribusi } \\
\text { normal }\end{array}$ \\
\hline
\end{tabular}

Untuk uji homogenitas, diperoleh $F_{\text {hitung }}=2,52$, sedangkan $F_{(0,05 ; 10 ; 9)}=$ 3,13, sehingga $F_{\text {hitung }}<F_{\text {tabel }}$. Jadi $H_{o}$ diterima dan $H_{a}$ ditolak. Dengan demikian varians populasi dari skor hasil kemampuan berpikir kritis siswa berdasarkan kelas eksperimen dan kelas kontrol adalah homogen.

Setelah data kedua kelas berdistribusi normal, dan varians kedua kelas homogen sehingga hipotesis data tes akhir yang diajukan dapat dianalisis melalui Uji- $F$ (Anova).

Hipotesis $1: \mu_{1}=7,669, \mu_{2}=4,06$, artinya $\mu_{1}>\mu_{2}$, maka $\mathrm{H}_{\mathrm{o}}$ ditolak dan $\mathrm{H}_{\mathrm{a}}$ diterima, sehingga dapat disimpulkan bahwa ada pengaruh strategi pembelajaran Relating, Experiencing, Applying, Cooperating, Transfering (REACT) terhadap kemampuan berpikir kritis siswa secara keseluruhan di SMP Sanudin Pangkalan Balai.

Hipotesis $2: \mu_{1}=46,56, \mu_{2}=3,21$, artinya $\mu_{1}>\mu_{2}$, maka $\mathrm{H}_{\mathrm{o}}$ ditolak dan $\mathrm{H}_{\mathrm{a}}$ diterima, sehingga dapat disimpulkan bahwa ada pengaruh strategi pembelajaran Relating, Experiencing, Applying, Cooperating, Transfering (REACT) terhadap kemampuan berpikir kritis ditinjau dari kemampuan awal siswa di SMP Sanudin Pangkalan Balai.

Hipotesis $3: \mu_{1}=-0,27, \mu_{2}=3,21$, maka $\mu_{1}<\mu_{2}$, sehingga $\mathrm{H}_{\mathrm{o}}$ diterima $\mathrm{H}_{\mathrm{a}}$ ditolak, maka dapat disimpulkan bahwa tidak ada interaksi strategi pembelajaran Relating, Experiencing, Applying, Cooperating, Transfering (REACT) dengan kemampuan awal (tinggi, sedang, rendah) terhadap kemampuan berpikir kritis siswa di SMP Sanudin Pangkalan Balai.

Selanjutnya sesuai dengan tujuan dari penelitian ini, maka gambaran dari masing-masing tujuan penelitian ini sebagai berikut:

1. Ada Pengaruh Strategi REACT Terhadap Kemampun Berpikir Kritis Siswa Secara Keseluruhan 
Berdasarkan hasil penelitian menunjukkan bahwa pada kelas eksperimen yang diberikan perlakuan strategi $R E A C \mathrm{~T}$ rerata skor akhir yang lebih tinggi dibandingkan dengan rerata kelas kontrol yang diberikan perlakuan pembelajaran konvensional. Dari hasil pertemuan kedua, ketiga, dan keempat di kelas VIII.2 sebagai kelas eksperimen dengan menggunakan strategi REACT dapat dikatakan mampu meningkatkan kemampuan berpikir kritis siswa dengan baik, hal ini terbukti dari hasil rata-rata siswa dalam mengerjakan soal evaluasi untuk mengukur kemampuan berpikir kritis pada setiap akhir pertemuan.

Pada pertemuan kedua di kelas eksperimen diberikan evaluasi untuk mengukur kemampuan berpikir kritis siswa, disebabkan aktifitas siswa yang belajar dengan strategi REACT selama proses pembelajaran awalnya siswa agak sedikit kaku. Hal ini dimaklumi karena pendekatan pembelajaran ini agak berbeda dengan pendekatan pembelajaran yang selama ini biasa dterima dari gurunya. Selain itu kondisi yang sangat berbeda adalah ketika siswa diminta mempresentasikan hasil kerja kelompok mereka, kemudian ditanggapi dari kelompok lain. Pada pertemuan kedua dan ketiga diberikan evaluasi untuk mengukur kemampuan berpikir kritis siswa. Secara umum, proses pembelajaran yang terjadi di kelas eksperimen telah sesuai dengan ramburambu dan kriteria yang telah ditetapkan, hal ini tercermin dari proses aktif siswa dalam diskusi, bertanya, menjawab permasalahan, menjelaskan dan menampilkan hasil pekerjaannya di depan kelas.

Jika dicermati hasil penelitian yang telah dikemukakan menunjukkan bahwa pembelajaran REACT memberikan pengaruh terhadap kemampuan berpikir kritis siswa dibandingkan pendekatan konvensional. Sedangkan pada kelas kontrol, diberikan pendekatan konvensional yang biasa digunakan guru matematika, seperti guru menjelaskan konsep dan contoh soal dilanjutkan dengan siswa mengerjakan soal latihan atau mengisi lembar kerja. Dalam pendekatan konvensional ini kadangkadang guru menjelaskan matematika melalui tanya jawab dan terkadang pula siswa dikelompokkan untuk menyelesaikan soal-soal latihan.

2. Ada Pengaruh Strategi Pembelajaran REACT Terhadap Kemampun Berpikir Kritis Ditinjau dari Kemampuan Awal Siswa Menurut Masing-Masing Level

Kemampuan awal siswa penting untuk diketahui guru sebelum dimulai pembelajaran karena dengan pengetahuan dan keterampilan yang dimiliki siswa sehingga mereka dapat mengikuti pelajaran dengan baik. Strategi pembelajaran REACT merupakan pembelajaran kontekstual dimana siswa tidak sekedar menghapal rumus, siswa juga diberikan kesempatan menggunakan konsep yang diperoleh dalam menyelesaikan masalah yang berkaitan dengan kehidupan sehari-hari. Hal ini menunjukkan bahwa strategi pembelajaran REACT melatih kemampuan berpikir kritis siswa.

Jika seseorang yang memiliki pengetahuan dan keterampilan yang tinggi dengan kemampuan berpikir kritis yang tinggi maka semakin tinggi pula hasil belajar yang diperoleh. Pada pembelajaran yang berlangsung dengan menggunakan strategi REACT dapat memicu timbulnya kemampuan berpikir kritis siswa sehingga diperoleh hasil belajar sesuai yang diinginkan dengan telah mengetahui kemampuan awal siswa sebelum memasuki tahap pembelajaran. Selain itu juga terbukti dari hasil data yang telah diperoleh sehingga ditarik kesimpulan terdapatnya pengaruh strategi pembelajaran REACT terhadap kemampun berpikir kritis ditinjau dari kemampuan awal siswa menurut masing-masing level. 
3. Tidak Ada Interaksi Antara Pembelajaran REACT dengan Kemampuan Awal (Tinggi, Sedang, Rendah) Terhadap Kemapuan Berpikir Kritis Siswa

Dilihat dari pembelajaran yang berlangsung, langkah strategi pembelajaran REACT yang memerlukan banyak waktu adalah langkah experiencing/kegiatan pengalaman langsung kendala umumnya siswa belum bisa mandiri untuk melakukan kegiatan sendiri, terlalu sering siswa bertanya apa yang tertera pada LKS. Disamping itu juga menemukan dari suatu masalah memang perlu pemikiran yang mendalam, jarang yang langsung terjawab.

Kemudian dalam kemampuan berpikir kritis memerlukan waktu yang lebih banyak juga, menghubungkan kasus demi kasus memerlukan pemikiran yang mendalam. Benturan antara langkah strategi REACT dan kemampuan berpikir kritis ini juga membuat siswa jenuh dalam melakukan proses belajar, sehingga hasil belajar tidak seperti yang diharapkan. Selain itu juga terbukti dari hasil perhitungan anova bahwa tidak ada interaksi strategi pembelajaran Relating, Experiencing, Applying, Cooperating, Transfering (REACT) dengan kemampuan awal (tinggi, sedang, rendah) terhadap kemampuan berpikir kritis siswa di SMP Sanudin Pangkalan Balai.

Jika dicermati hasil penelitian ini sejalan dengan yang telah dikemukakan oleh peneliti sebelumnya, yaitu Herawati (2013) dan Aziz (2014) bahwa siswa yang mengikuti pembelajaran melalui strategi REACT secara signifikan mengalami peningkatan kemampuan berpikir kritis matematisnya, serta respon positif siswa terhadap pembelajaran strategi REACT.

Strategi pembelajaran REACT merupakan suatu pendekatan pembelajaran kontekstual yang berhubungan dengan pengalaman dan penerapan pemahaman dalam berbagai konteks, baik di dalam maupun di luar kelas untuk menyelesaikan permasalahan. REACT merupakan strategi pembelajaran konteks yang didasarkan pada bagaimana siswa belajar untuk mendapatkan pemahaman dan bagaimana guru mengajarkan untuk memberikan pemahaman. Strategi REACT diyakini dapat membantu guru dalam meningkatkan kemampuan dan pemahaman matematika siswa karena pada pembelajaran dengan strategi REACT siswa tidak sekedar menghapal rumus, tetapi siswalah yang mengkonstruksi pengetahuannya dengan mengaitkan konsep yang dipelajari dengan konteks yang dikenali siswa dan ikut aktif dalam menemukan konsep yang dipelajari sehingga pembelajaran lebih bermakna.

Pada strategi REACT, siswa juga diberikan kesempatan untuk menggunakan konsep yang diperoleh dalam menyelesaikan masalah yang berkaitan dengan kehidupan sehari-hari. Hal ini menunjukkan bahwa strategi pembelajaran REACT dapat melatih kemampuan berpikir kritis siswa.

Berpikir kritis adalah keterampilan bernalar dalam proses pengambilan keputusan untuk memecahkan masalah yang difokuskan untuk memutuskan hal-hal yang harus diyakini dan dilakukan.

Kemampuan awal siswa merupakan kemampuan yang telah dipunyai oleh siswa sebelum ia mengikuti pembelajaran yang akan diberikan. Kemampuan awal ini menggambarkan kesiapan siswa dalam menerima pelajaran yang disampaikan oleh guru. Kemampuan awal siswa dilihat dari tes soal matematika.

Sedangkan pembelajaran yang dilakukan di kelas kontrol adalah dengan pembelajaran konvensional. Pembelajaran konvensional merupakan pembelajaran yang biasa digunakan oleh guru dimana pembelajarannya kebanyakan masih berpusat pada guru dengan menggunakan metode ceramah, karena sejak dulu telah 
digunakan sebagai alat komunikasi lisan antara guru dengan siswa. Dalam pembelajaran konvensional guru menyampaikan pokok-pokok materi pembelajaran, guru memberikan contoh soal, guru memberikan kesempatan pada siswa untuk bertanya bila kurang jelas, guru memberikan latihan soal kemudian dibahas bersama dan setelah itu guru mengulas kembali materi yang telah dipelajari.

Pada pembelajaran konvensional pembelajaran di dalam kelas lebih didominasi oleh guru sehingga siswa menerima informasi secara pasif. Sehingga guru kesulitan untuk mengetahui kemampuan siswa apakah sudah paham atau belum mengenai materi yang telah disampaikan. Oleh karena itu kemampuan berpikir kritis siswa kelas kontrol lebih rendah dari pada kelas eksperimen.

\section{SIMPULAN}

Berdasarkan analisis data penelitian, maka dari penelitian ini dapat disimpulkan bahwa : 1) Ada pengaruh strategi pembelajaran Relating, Experiencing, Applying, Cooperating, Transfering (REACT) terhadap kemampuan berpikir kritis siswa secara keseluruhan di SMP Sanudin Pangkalan Balai. 2) Ada pengaruh strategi pembelajaran Relating, Experiencing, Applying, Cooperating, Transfering (REACT) terhadap kemampuan berpikir kritis ditinjau dari kemampuan awal siswa menurut masing-masing level di SMP Sanudin Pangkalan Balai. 3) Tidak ada interaksi antara pembelajaran Relating, Experiencing, Applying, Cooperating, Transfering (REACT) dengan kemampuan awal (tinggi, sedang, rendah) terhadap kemampuan berpikir kritis siswa di SMP Sanudin Pangkalan Balai

\section{DAFTAR PUSTAKA}

Astuti, Siwi Puji. 2015. Pengaruh Kemampuan Awal dan Minat Belajar Terhadap Prestasi Belajar Fisika. Formatif, Vol. 5(1): 68-75.

Azis, Samsul. 2014. Penerapan Strategi REACT dengan Pendekatan Education Games Untuk Meningkatkan Kemampuan Berpikir Kritis Siswa Pada Materi Bangun Ruang Sisi Lengkung Kelas VIII SMP IT Bina Amal Semarang. Skripsi tidak diterbitkan. Semarang: Jurusan Matematika FMIPA Universitas Negeri Semarang. [Online] Tersedia: http://lib.unnes.ac.id/23099/1/4101407076.pdf

Cord. 1999. Teaching Mathematics Contextually. Waco, Texas: CORD Communications, Inc.

Dwijananti, P. dan Yulianti, D. 2010. Pengembangan Kemampuan Berpikir Kritis Mahasiswa Melalui Pembelajaran Problem Based Instruction Pada Mata Kuliah Fisika Lingkungan. Jurnal Pendidikan Fisika Indonesia, Vol. 6 (2) : 108-114.

Fisher, Alec. 2008. Berpikir Kritis Sebuah Pengantar. Jakarta: Erlangga.

Herawati, Linda. 2013. Pembelajaran Melalui Strategi REACT Untuk Meningkatkan Kemampuan Pemahaman dan Berpikir Kritis matematis Siswa SMK di Kota Tasikmalaya. Tesis tidak diterbitkan. Jakarta: Program Pascasarjana Universitas Terbuka. [Online] Tersedia: http://repository.ut.ac.id/1539/

Muhaimin dkk. 2008. Pengembangan Model Kurikulum Tingkat Satuan Pendidikan (KTSP) pada Sekolah \& Madrasah. Jakarta: PT RajaGrafindo Persada.

Mukhtar. 2003. Desain Pembelajaran Pendidikan Agama Islam. Cet 1. Jakarta: CV Misaka Galiza. 
Noor, Aisjah Juliani dan Raisah. 2015. Penerapan Strategi Relating Experiencing Applying Cooperating Transfering (REACT) dalam Pembelajaran Geometri di Kelas X SMA. EDU-MAT, Vol. 3(2) : 196-203.

Syahbana, Ali. 2012. Pengembangan Perangkat Pembelajaran Berbasis Kontekstual Untuk Mengukur Kemampuan Berpikir Kritis Matematis Siswa SMP. Edumatica, Vol. 2(2) : 17-26. 